\title{
Influence of hydrographic conditions on picoplankton distribution in the East China Sea
}

\author{
Nianzhi Jiao ${ }^{1, *}$, Yanhui Yang ${ }^{1}$, Hiroshi Koshikawa ${ }^{2}$, Masataka Watanabe ${ }^{2}$ \\ ${ }^{1}$ Ministry of Education Key Laboratory for Marine Environmental Sciences, Center for Environmental Sciences, \\ University of Xiamen, Fujian 361005, PR China \\ ${ }^{2}$ National Institute of Environmental Studies, Tsukuba, Ibaraki 3050053, Japan
}

\begin{abstract}
An investigation was made on picoplankton distributions in relation to physical and chemical conditions in the East China Sea, a marginal sea of the Northwest Pacific, in July 1998. Synechococcus, pico-eukaryotes and heterotrophic bacteria were ubiquitous, with average abundance at the order of $10^{4}, 10^{2}$ and $10^{5}$ cells ml ${ }^{-1}$, respectively. Prochlorococcus was present at most locations beyond the $50 \mathrm{~m}$ isobath at around $10^{4}$ cells $\mathrm{ml}^{-1}$. Responses of these picoplankters to the hydrographic conditions were evident in both vertical and horizontal distributions. Prochlorococcus were basically associated with oceanic warm currents, and sudden changes in cell abundance often occurred within a relatively short distance of the currents. In the surface mixed layer, Prochlorococcus were usually present only when temperature was $>26^{\circ} \mathrm{C}$, salinity $>30$ psu, total inorganic nitrogen $<3 \mu \mathrm{M}$ and phosphate $<0.4 \mu \mathrm{M}$ in the study period. Vertically, however, Prochlorococcus were distributed down where temperature was as low as $16^{\circ} \mathrm{C}$ and nutrient levels were also higher. No pronounced subsurface peaks in Prochlorococcus abundance were recorded in the oceanic warm currents although Prochlorococcus outnumbered Synechococcus by at least an order of magnitude. Synechococcus were most abundant in the coastal area associated with high nutrient levels. Picoeukaryotes usually developed very well in the front areas on the continental shelf. Along offshore directions, pico-eukaryotes often centered farther from the shore and deeper in the water column than did Synechococcus. Heterotrophic bacteria showed the least variation in abundance among the 4 picoplankters, but still decreased distinctly in offshore directions, following a similar trend in the total biomass of pico-eukaryotes and Synechococcus. In the Yangtze River plume area, light availability was also important in regulating picoplankton distribution patterns. The relationship between Prochlorococcus and bacteria biomass was negative along gradients in the marginal sea.
\end{abstract}

KEY WORDS: Prochlorococcus · Synechococcus - Pico-eukaryotes · Heterotrophic bacteria · Picoplankton · East China Sea

Resale or republication not permitted without written consent of the publisher

\section{INTRODUCTION}

Prochlorococcus, divinyl chlorophyll containing tiny photoautotrophs (Chisholm et al. 1988, 1992) together with Synechococcus, pico-eukaryotes and heterotrophic bacteria are the principal components of the marine picoplankton community, and can be identified and quantified by flow cytometry (Olson et al.

*Email: jiao@xmu.edu.cn
1988, Marie et al. 1997). Ecological studies on Prochlorococcus and the other groups of picoplankton have been carried out extensively in oceanic waters of the Pacific (e.g. Campbell \& Vaulot 1993, Binder et al. 1996), Atlantic (e.g. Olson et al. 1990, Li 1995, Buck et al. 1996), Mediterranean Sea (e.g. Vaulot et al. 1990, Bustillos-Guzman et al. 1995), and Arabian Sea (e.g. Campbell et al. 1998). Picoplankton have been considered to play critical roles in marine ecosystems. Although Prochlorococcus have been found in the plume of the Rhône River in the 
Mediterranean Sea (Vaulot et al. 1990), such coastal studies are still rare. Questions remain as to whether Prochlorococcus can grow actively in coastal waters or are simply advected from oceanic water (Partensky et al. 1999). The features of picoplankton distribution in marginal seas and the controlling factors remain unclear. The East China Sea is one of the largest continental marginal seas in the world, with nutrient-replete water in the coastal areas and oligotrophic oceanic waters along the Kuroshio Current coming from the western equatorial Pacific. It is thus ideally suited for ecological studies (Furuya et al. 1996, Hama et al. 1997). However, little is known about the structure and dynamics of the picoplankton communities in this area. Prochlorococcus have been verified to be present in certain areas of this sea (Jiao et al. 1998, Jiao \& Yang 1999), but its regulation mechanisms remain largely unknown. A few reports of Synechococcus and heterotrophic bacteria exist but simultaneous observations of the 4 picoplankton groups are absent. The purpose of this study was to investigate population dynamics of these 4 groups of picoplankton as well as relevant physical and chemical factors in an attempt to understand the factors that affect the distribution of Prochlorococcus and other picoplankters in the temperate marginal sea.

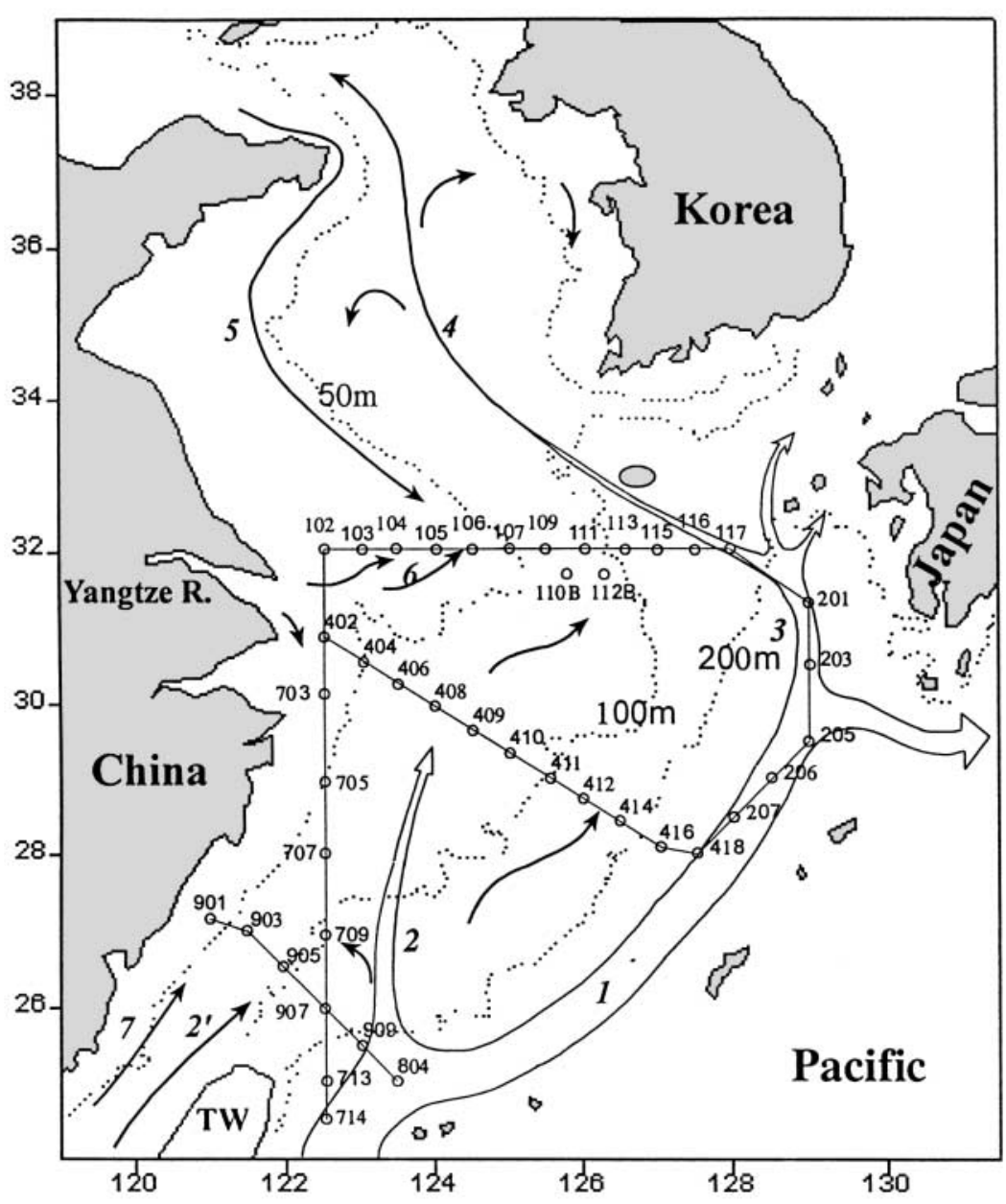

Fig. 1. Location of the East China Sea, the main currents, and sampling stations in July 1998. 1: Kuroshio Current; 2 and 2': Taiwan Warm Current; 3: Tsukuma Current; 4: Yellow Sea Warm Current; 5: the Yellow Sea Coastal Current; 6: Yangtze River diluted water; 7: the East China Sea Coastal Current. The locations of the currents are after Su (1989) with modifications according to the temperature and salinity data of the present cruise. Transects 1, 2, 4, 7 and 9 are indicated by the first digits of the corresponding sampling stations

\section{MATERIALS AND METHODS}

The East China Sea (ECS) is located on the western edge of the Northwest Pacific Ocean, and is characterized by a vast continental shelf and diverse environmental conditions. The main water masses are the Yangtze River diluted water in the west, the Yellow Sea Coastal Current from north to south along the northwest coast of the sea, the Yellow Sea Cold Eddy (Sawarh 1974) in the north, the Kuroshio Current coming from the western equatorial Pacific in the east, and the Taiwan Warm Current in the south. Thus, the ECS can be divided into 3 regions by the main currents and water masses. The coastal region is affected strongly by the Yangtze River water and the coastal currents.
The deep water region along the east edge of the sea is strongly affected by the Kuroshio Current and Taiwan Warm Current and characterized by relatively low nutrients and high temperature; the transitional region between the 2, where currents and water masses meet, mix and interact, makes up the most important part of the continental shelf. Forty-two stations along 5 transects (1, 2, 4, 7 and 9) were investigated in July 1998 (Fig. 1).

Water samples were collected at $0,10,20,30,50,75$, 100 and $150 \mathrm{~m}$ depths using Niskin bottles (Oceanic). Samples for flow cytometry analysis were fixed with glutaraldehyde (final conc.: 1\%, Vaulot et al. 1989), quick-frozen in liquid nitrogen and stored in a freezer at $-20^{\circ} \mathrm{C}$ for later analysis. Samples were run on a 
FACSCalibur flow cytometer (Becton-Dickinson), equipped with an external quantitative sample injector (Harvard Apparatus PHD 2000). Procedures were as described by Olson et al. (1990). The 3 autotrophs were distinguished according to their positions in plots of red fluorescence (FL3) versus $90^{\circ}$ angle light scatter (SSC), and orange fluorescence (FL2) versus SSC. Pico-eukaryotes were identified by their large size and red fluorescence. SYBR Green I (Molecular Probes) was applied as the nucleic acid stain (Marie et al. 1997) for bacteria identification in plots of FL3 versus green fluorescence (FL1). Samples for flow cytometry enumeration of autotrophs were run separately from those for heterotrophic bacteria. Flow cytometry data were collected in list mode, and analyzed with CytoWin 4.1 software provided by D. Vaulot (Station Biologique, Roscoff, France. Software is available from www.sbroscoff.fr/Phyto/cyto.html). Data for nutrients, temperature, salinity, and transparency were from the Chinese JGOFS cruise project reports of the same cruise.

\section{RESULTS}

\section{Physical and chemical conditions}

During the study period, surface water temperature ranged from $30^{\circ} \mathrm{C}$ in the oceanic water to $25^{\circ} \mathrm{C}$ in the northwest coastal area. Nutrient levels in the coastal region were high. Total inorganic nitrogen (TIN) was usually higher than $4 \mu \mathrm{M}$ and reached up to $13 \mu \mathrm{M} ; \mathrm{PO}_{4}-\mathrm{P}$ was usually higher than $0.3 \mu \mathrm{M}$ and reached up to $1.0 \mu \mathrm{M}$. Nutrient levels in the deep water region were usually low (TIN $<2 \mu \mathrm{M}, \mathrm{PO}_{4}$-P ca. $0.2 \mu \mathrm{M}$ ). The transitional region was variable with TIN from 1 to $10 \mu \mathrm{M}$ and $\mathrm{PO}_{4}-\mathrm{P}$ from 0.2 to $0.8 \mu \mathrm{M}$ ). Salinity ranged from more than $34 \mathrm{psu}$ in the southeast region to less than $20 \mathrm{psu}$ in the Yangtze River estuary. Transparency was 0.8 to $3.5 \mathrm{~m}$ in the estuarine area, and more than $40 \mathrm{~m}$ in the clear waters of the Kuroshio Current region. Most of the investigation sites were stratified and nitraclines usually developed (Figs. $2 \& 3$ ).

\section{Picoplankton distribution patterns and affecting factors}

In the Yangtze River plume, there were strong horizontal and vertical gradients in nutrients, salinity, temperature and transparency from the river mouth to the adjacent radiation areas, and pronounced responses in picoplankton distribution were recorded (Fig. 4; also see Fig. 5a,c), e.g. at Stn 103, transparency was only $2.5 \mathrm{~m}$, salinity increased from $25 \mathrm{psu}$ at the surface to 32 psu below $20 \mathrm{~m}$. The surface layer was obviously

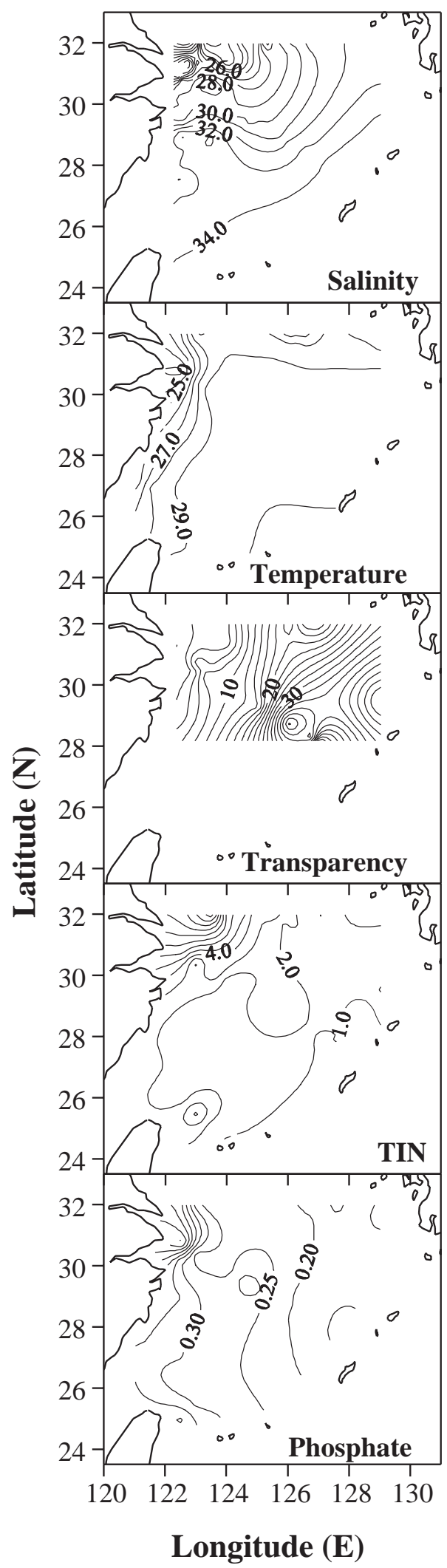

Fig. 2. Distribution of surface salinity (psu), temperature $\left({ }^{\circ} \mathrm{C}\right)$, transparency $(\mathrm{m})$, total inorganic nitrogen (TIN, $\mu \mathrm{M})$ and phosphate $(\mu \mathrm{M})$ 


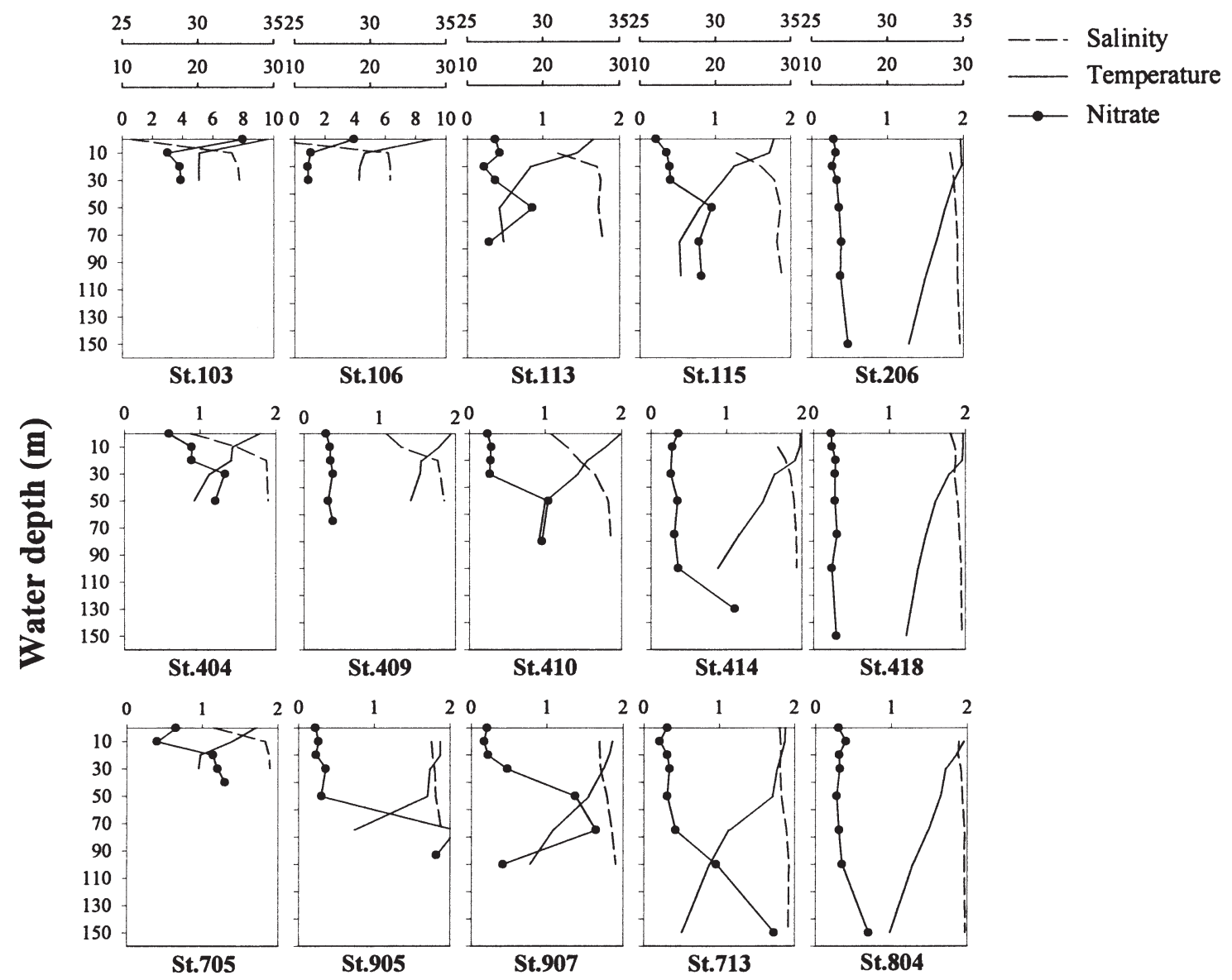

Fig. 3. Depth profiles of salinity (psu), temperature $\left({ }^{\circ} \mathrm{C}\right)$ and nitrate $(\mu \mathrm{M})$ at some typical stations (St.)

diluted by freshwater. Nitrate was about $8 \mu \mathrm{M}$ at the surface and reduced abruptly to $3 \mu \mathrm{M}$ within $10 \mathrm{~m}$. Abundance maxima of Synechococcus and bacteria occurred at the surface. Bacteria were very abundant, with depth-weighted average cell abundance reaching a level of $1.2 \times 10^{6}$ cells ml ${ }^{-1}$. Cell abundances of Synechococcus and pico-eukaryotes were relatively low, with depth-weighted averages of $1.0 \times 10^{4}$ and $1.1 \times$ $10^{2}$ cells $\mathrm{ml}^{-1}$ respectively. At Stn 106 (where both nutrient and turbidity were lower than at Stn 103), situated on the outer edge of the plume, cell abundances of Synechococcus and pico-eukaryotes were 8- and 5fold higher, respectively, than those at Stn 103, and the abundance peaks deepened to $10 \mathrm{~m}$. However, cell abundance of bacteria decreased to $1.0 \times 10^{6} \mathrm{cells} \mathrm{ml}^{-1}$ due to less availability of organic carbon from the river input (Zhao 2000). At Stn 404 (which is opposite Stn 103 on the other side of the plume, although with similar distance to the Yangtze River mouth), the transparency was much higher and nutrients were much lower than those at Stn 103 because of the lesser impact of land input. Synechococcus and pico-eukary- otes were more abundant $\left(5.0 \times 10^{4}\right.$ and $8.6 \times 10^{2}$ cells $\mathrm{ml}^{-1}$, respectively) and bacteria were less abundant $\left(5.4 \times 10^{5}\right.$ cells $\left.\mathrm{ml}^{-1}\right)$ at Stn 404 compared with at Stn 103 (Figs. 3 \& 4). On the other hand, while light limitation was less influencing here, nutrient availability became stressing. Picoplankton at this station followed the nitrate depth profile and peaked at a subsurface layer deeper than that at Stn 106, where turbidity was similar but nutrient was much higher at the surface (Figs. 3 \& 4). There was no Prochlorococcus present in this region. Light as well as nutrient availability seemed to play a critical role in determining picoplankton distribution patterns in the plume area.

Out of the estuarine area in the north part of the sea, the Yellow Sea Coastal Current met the Yangtze River plume and turned to the east, together with the eddy, centered at around Stn 111, and formed a cold water mass west of Stn 113 (Figs. 1 \& 5a, Temp). Beyond Stn 113, water temperature was distinctly higher because a branch of Kuroshio Current passing though Stns 116 and 117 (Fig. 1). In the front area in between the cold and warm water masses at Stn 113, tempera- 


\section{Cell abundance (cells $\mathbf{m l}^{-1}$ )}

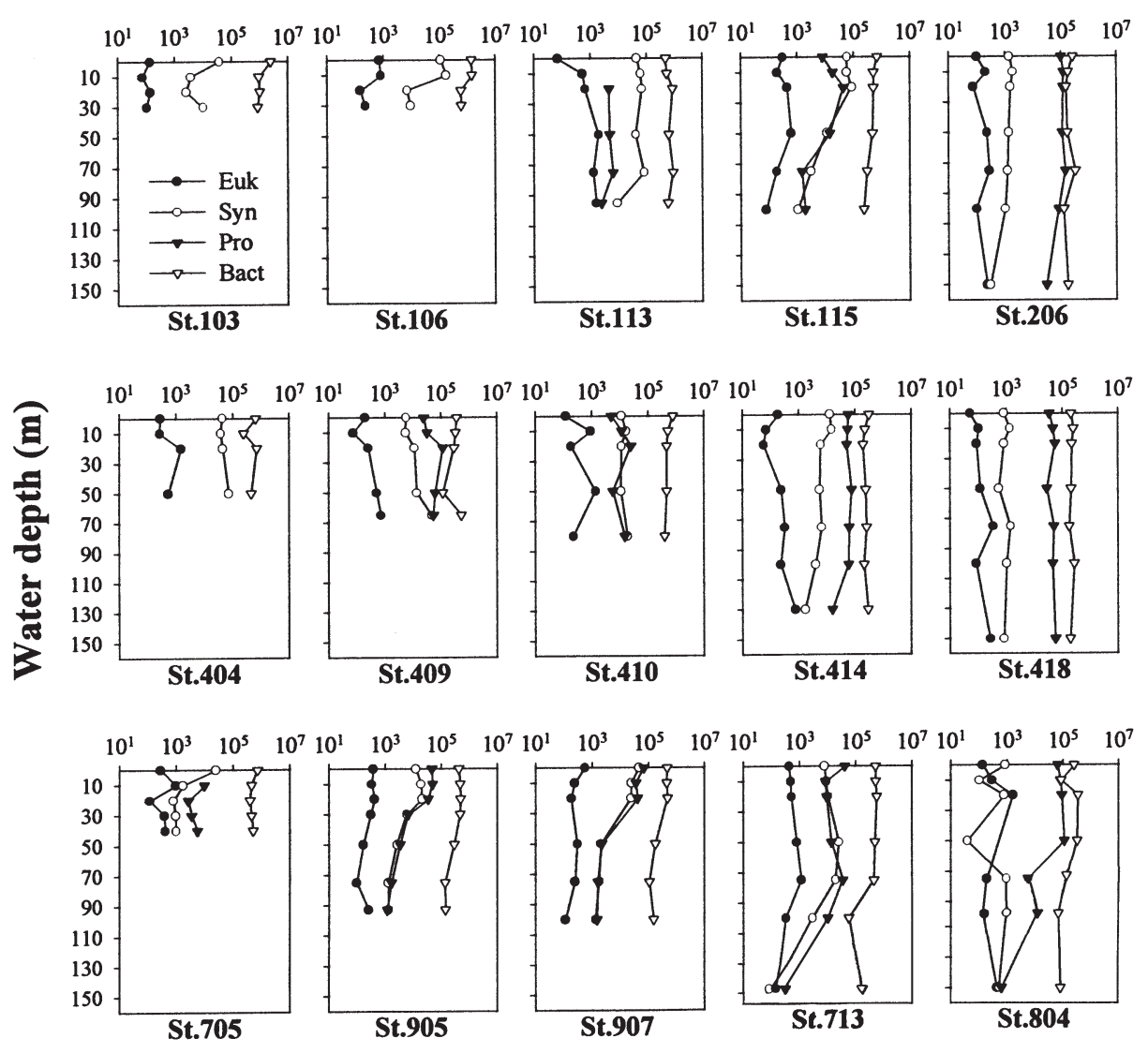

Fig. 4. Picoplankton depth profiles at some typical stations. $x$-axis in logarithmic scale. Euk: picoeukaryotes; Syn: Synechococcus; Pro: Prochlorococcus; Bact: heterotrophic bacteria

ture was $26.5^{\circ} \mathrm{C}$ at the surface, $18^{\circ} \mathrm{C}$ at $20 \mathrm{~m}$ and down to less than $14^{\circ} \mathrm{C}$ at $50 \mathrm{~m}$ (Fig. 3, Stn 113). Depthweighted average of pico-eukaryotes reached $1.2 \times$ $10^{3}$ cells $\mathrm{ml}^{-1}$, with maximum abundance $\left(2 \times 10^{3}\right.$ cells $\mathrm{ml}^{-1}$ ) occurring at around $50 \mathrm{~m}$, corresponding to the maximum nitrate concentration depth (Fig. 4, Stn 113). This was one of the 2 high abundance zones of picoeukaryotes; the other one was at another front area, Stn 406 (see below). Synechococcus and bacteria were also more abundant at the subsurface layer (down to $80 \mathrm{~m}$ ) than at the surface $20 \mathrm{~m}$ layer. Prochlorococcus began to appear at Stn 113. From here eastward along this transect, Synechococcus, pico-eukaryotes and bacteria all decreased dramatically; Prochlorococcus, in contrast, increased up to $1.2 \times 10^{5}$ cells $\mathrm{ml}^{-1}$ at the east end of the transect. Distinct differences in the distributions of different picoplankters can be seen from Transect 1 (Fig. 5a). Prochlorococcus was confined to the outer region (east of Stn 113), where a branch of Kuroshio Current passes through (Fig. 1). Synechococcus peaked in the outer part of the plume, where nutrients were still replete but turbidity was not that high (around Stn 105, transparency was more than $6 \mathrm{~m}$ ), while pico-eukaryotes peaked immediately outside the plume (Stn 107) and formed another high abundance zone in the front area (Stn 113). A high abundance of bacteria was associated with coastal waters.

On the main continental shelf of the ECS, picoplankton distributions were more complex because of interacting water masses. Transect 4 passed through 2 main warm water currents in a perpendicular direction. One was the Kuroshio Current principal in the outer region of the sea (affecting Stns 414, 416 and 418), the other was Taiwan Warm Current main branch coming from the northeast of Taiwan island affecting Transect 4 at around Stns 408 and 409 (Figs. 1 \& 5c, Temp, NO ). In these 2 areas, stratifications were weak and nutrient levels were very low (nitrate was down to $0.2 \mu \mathrm{M}$ ) and nitraclines were deep (down to $100 \mathrm{~m}$ ) or absent (Fig. 3). Abundance of Prochlorococcus was around $5 \times$ $10^{4}$ cells $\mathrm{ml}^{-1}$, much higher than those of the other 2 autotrophs (Fig. 4, Stns 409, 414 and 418). In between the 2 warm water masses, there was a transitional region around Stns 410 to 412 , where the thermocline 


\section{a}

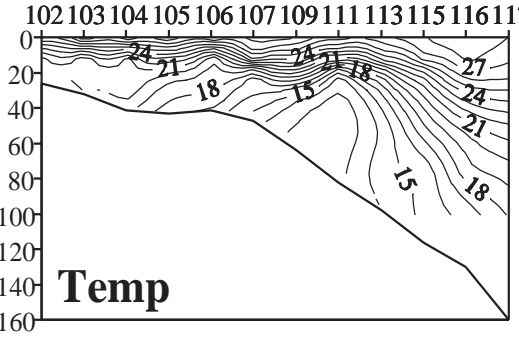

102103104105106107109111113115116117

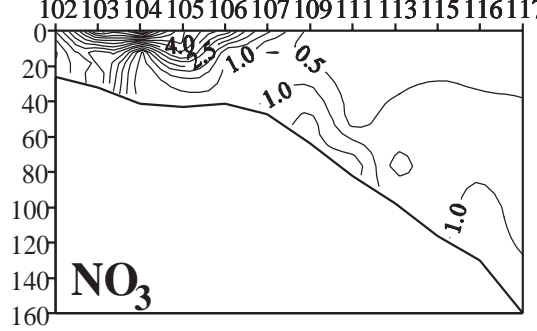

102103104105106107109111113115116117

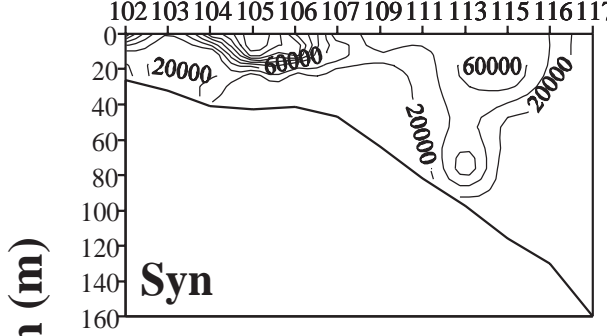

102103104105106107109111113115116117

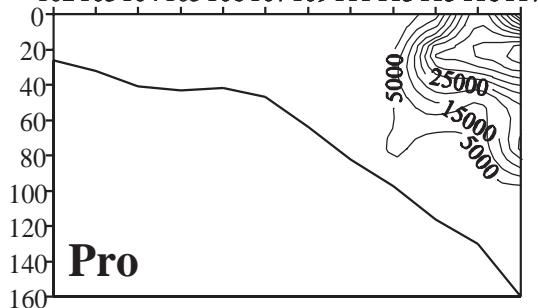

102103104105106107109111113115116117
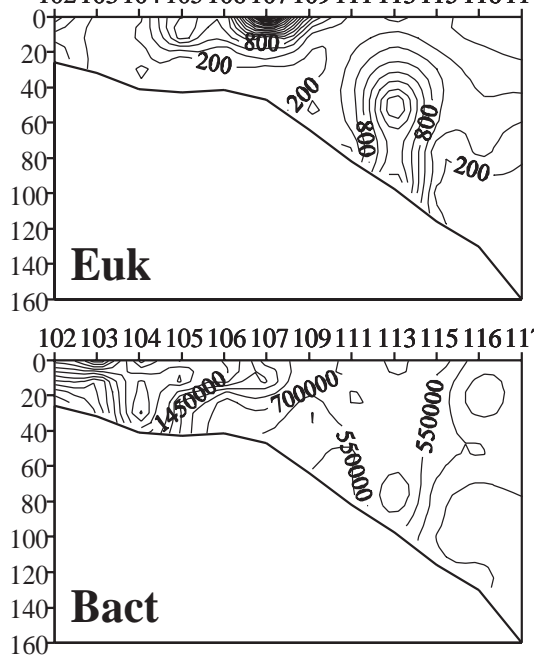

b
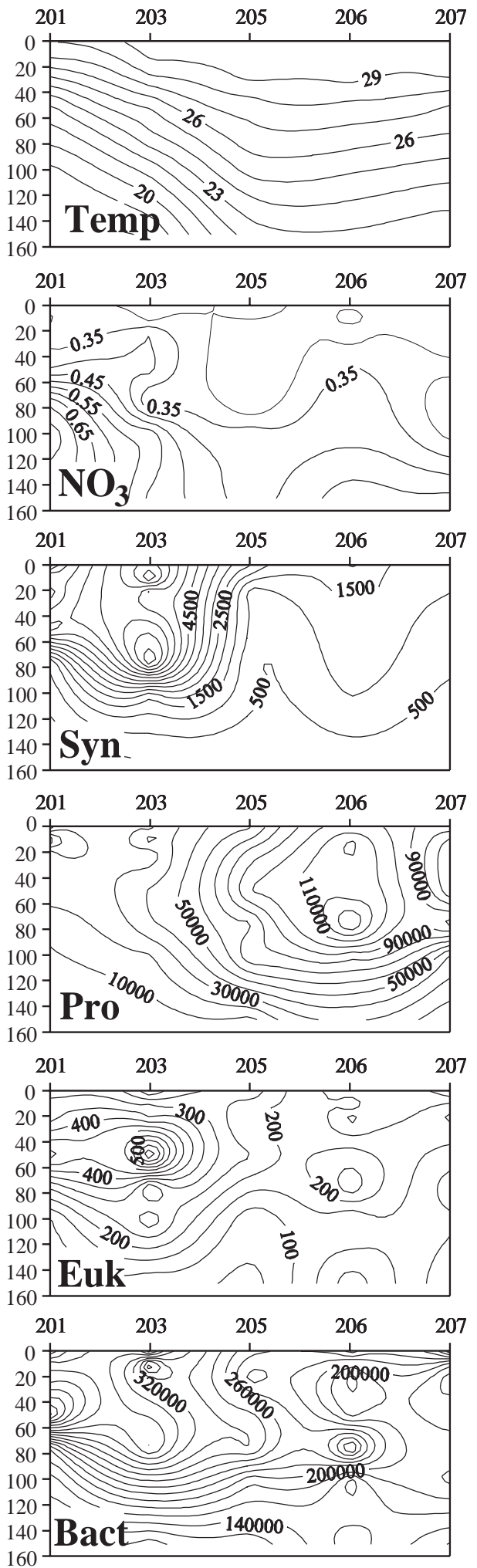

Station
C

402404406408409410411412414416418

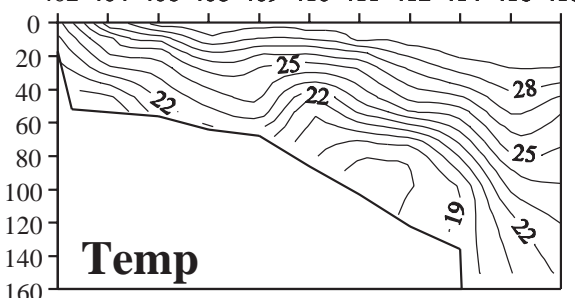

402404406408409410411412414416418

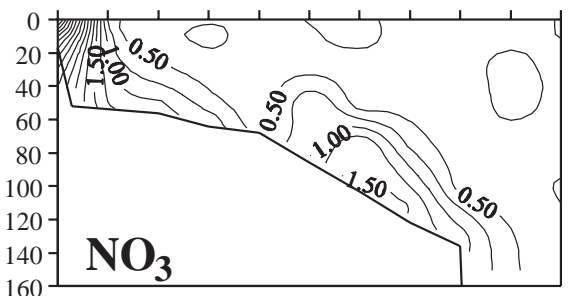

402404406408409410411412414416418

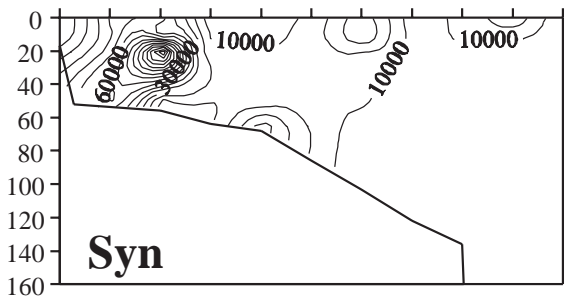

402404406408409410411412414416418

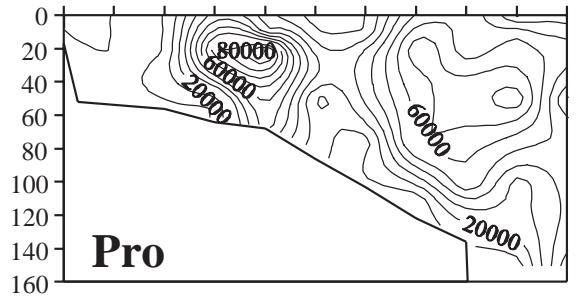

402404406408409410411412414416418

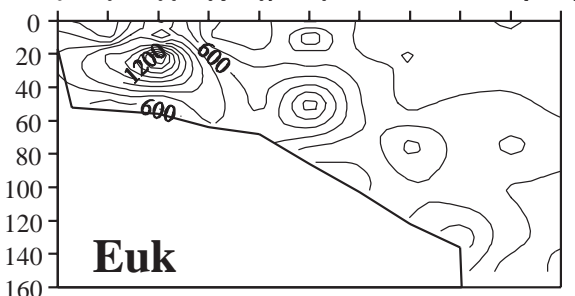

402404406408409410411412414416418

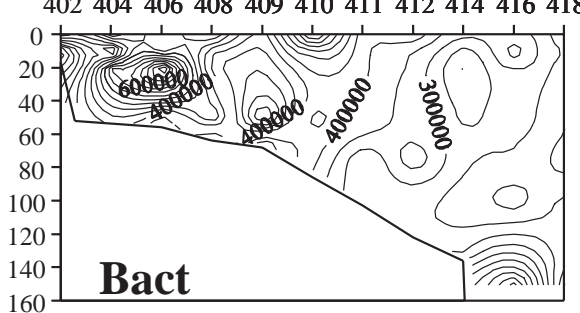

Fig. 5. (Above and facing page.) Vertical distributions of temperature (Temp, $\left.{ }^{\circ} \mathrm{C}\right)$, nitrate $\left(\mathrm{NO}_{3}, \mu \mathrm{M}\right)$, Synechococcus $(\mathrm{Syn})$, Prochlorococcus (Pro), pico-eukaryotes (Euk) and heterotrophic bacteria (Bact) along transects (a) 1, (b) 2, (c) 4, (d) 7 and (e) 9. Unit of picoplankton: cells $\mathrm{ml}^{-1}$ 


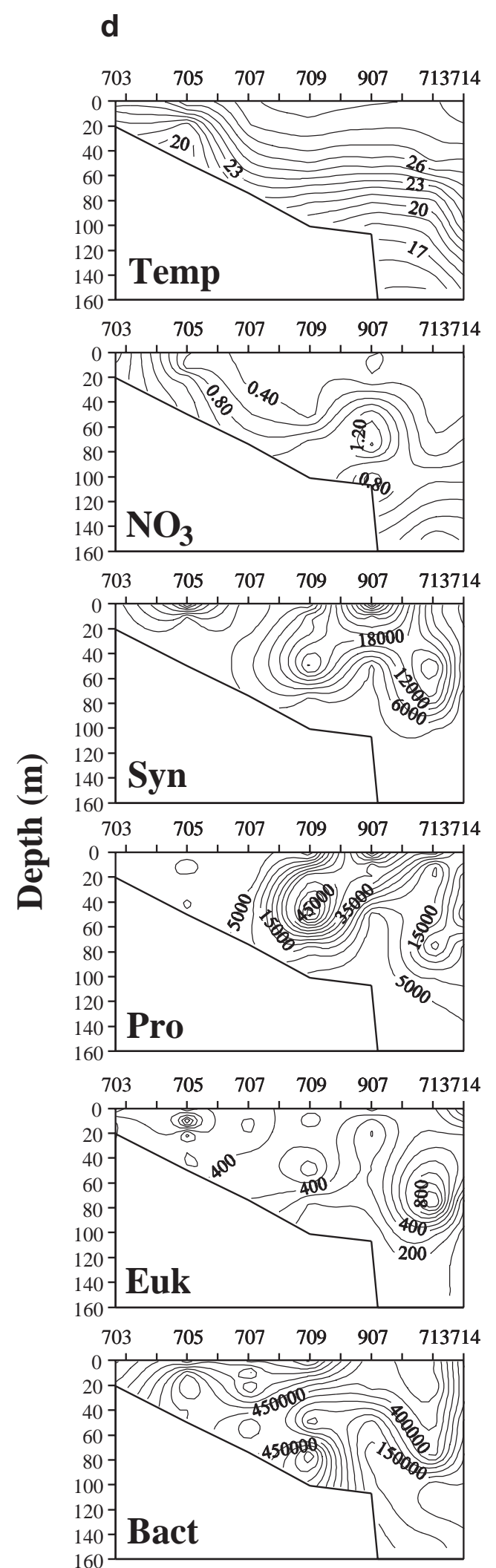

\section{e}
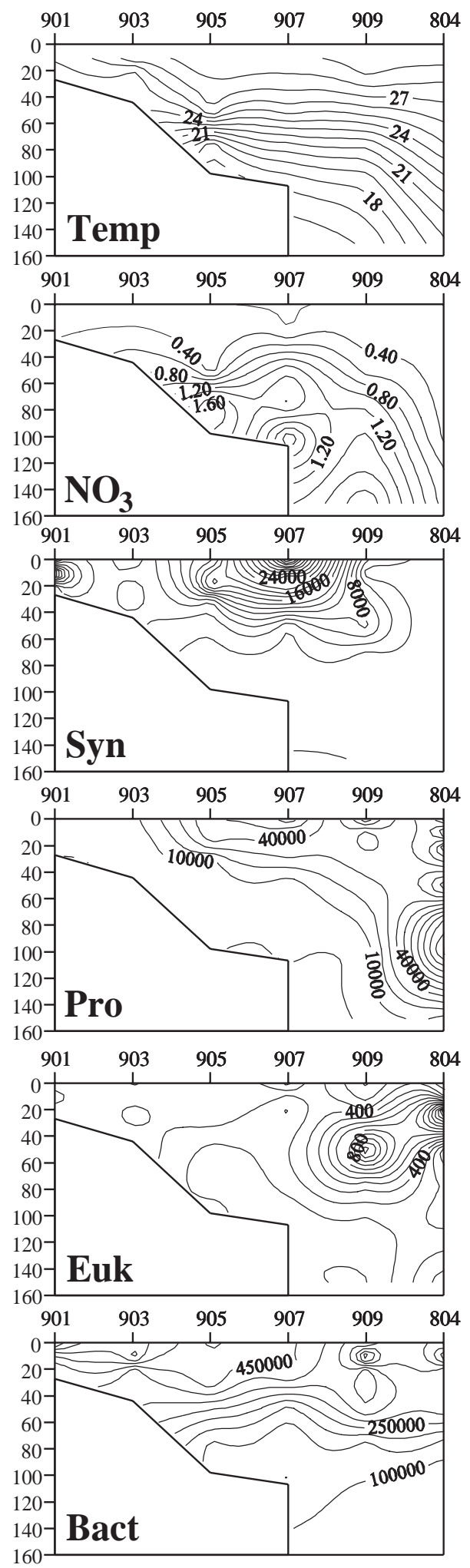

\section{Station}

Fig. 5 (continued) 
and nitracline developed at around $50 \mathrm{~m}$ (Fig. 3, Stn 410). A significant biological feature of this region was that pico-eukaryotes thrived to a high abundance just next to the highest of $1.4 \times 10^{3}$ cells ml $^{-1}$ recorded in the further coastal area Stn 406 (Fig. 5c, Euk). Distinct patterns in picoplankton distribution can be seen along Transect 4 (Fig. 5c). Prochlorococcus was associated with the warm currents, dominating numerically in the center and east edge of the sea. Synechococcus was abundant in the estuarine adjacent waters but not the high turbidity area. Pico-eukaryotes displayed a pattern similar to Synechococcus but were more deeply distributed (Fig. 5c, Euk). Bacteria, presumably unaffected by light availability, centered closest to the river input of high turbidity and high nutrients.

Transect 7, set from out of the Yangtze River estuary to the south edge of the sea (Fig. 1), was mainly affected by the Kuroshio Current (Stn 714) and Taiwan Warm Current in the southern part (Stn 709, Figs. 1 \& 5d). Prochlorococcus centered at around $50 \mathrm{~m}$ of the 2 currents correspondingly. Synechococcus showed a very interesting pattern along this transect, peaking in between the 2 warm water masses at the surface of Stn 907 along with another center at the surface around Stn 705. On the other hand there were also 2 subsurface high Synechococcus abundance centers similar to those of Prochlorococcus at Stns 709 and 713. Pico-eukaryotes formed one center at the surface of Stn 705 and another at $75 \mathrm{~m}$ of Stn 713, which was deeper than that of Synechococcus and similar to that of Prochlorococcus. Distribution of bacteria along this transect seemed to follow the overlay of autotrophs.

Transect 9 together with Stn 804 formed another gradient from coastal water to oceanic Kuroshio Current water (Figs. $1 \& 5 \mathrm{e}$ ). In between the coastal water and the Kuroshio water, another branch of Taiwan Warm Current passed through this transect at around Stn 905. Prochlorococcus were sparse in the coastal water but very abundant (maximum of $1.2 \times 10^{5}$ cells $\mathrm{ml}^{-1}$ at $50 \mathrm{~m}$ at Stn 804) in the oceanic water. Again Synechococcus centered at the very coast and in between the 2 warm waters at Stn 907 (around $1.5 \times$ $10^{4}$ cells ml ${ }^{-1}$ ). Pico-eukaryotes were less abundant in the coastal area and were quite different in distribution pattern in terms of their relationship to Synechococcus and other picoplankton. They centered at the subsurface layer of Stn 909, and the front area and surface layer of Stn 804. The distribution pattern of bacteria at this transect was not typical but somewhat similar to that of the overlay of autotrophs.

In depth profile, 3 typical patterns can be seen at Stns 905, 907 and 804 (Figs. 3 \& 4). At Stn 907, nitracline occurred at about 20-40 m, and temperature decreased gradually from the surface to the bottom of the euphotic zone. Picoplankton peaked at the very surface. In contrast, at Stn 905, strong thermocline and nitracline deepened to 50-70 m. Prochlorococcus, Synechococcus and bacteria were distributed down to the same depth and peaked at about $20 \mathrm{~m}$. At Stn 804, where nitrate was low (around $0.2 \mu \mathrm{M}$ ) in the whole water column, Prochlorococcus abundance was at least an order of magnitude higher than the other autotrophs and was abundant at all the sampling depths in the upper $100 \mathrm{~m}$, reflecting a typical oligotrophic condition.

Along the Kuroshio Current branch from Stn 207 to Stn 201, water column structure was relatively uniform and similar to that at Stn 804 in the far south (Fig. 3) but the oceanic current became weaker and shallower (Fig. 5b). Correspondences in picoplankton were seen from their abundance. Prochlorococcus gradually decreased from a magnitude of $10^{5}$ cells $\mathrm{ml}^{-1}$ in the south to less than half of that in the north. All the other 3 picoplankters, especially pico-eukaryotes, were increasing in the same direction (Fig. 5b, Syn, Pro, Euk and Bact).

\section{DISCUSSION}

\section{Impacts of the Yangtze River and picoplankton distribution patterns along trophic gradients}

The Yangtze River is one of the largest rivers in the world. Tremendous amounts of nutrients and other materials carried by the freshwater runoff input into the sea greatly impacting the estuarine ecosystem. In conjunction with the oligotrophic Kuroshio Current on the other side of the sea, distinct gradients in nutrients, turbidity and salinity are formed across the continental shelf (Fig. 2). Corresponding patterns in picoplankton distribution could be recognized.

Prochlorococcus were very abundant in the southern and eastern regions of the sea where warm currents pass through, and declined gradually in abundance along warm water radiations to inshore direction on the continental shelf, and then disappeared in the Yangtze River estuarine area. By plotting cell abundance against nutrients, it can be seen that Prochlorococcus were only present where TIN was less than $3 \mu \mathrm{M}$ and phosphate less than $0.4 \mu \mathrm{M}$ (Fig. 6a,b). As in the Arabian Sea (Campbell et al. 1998), Prochlorococcus in the ECS were inversely correlated with macronutrients (Table 1). However this relationship may not be causative since Prochlorococcus can tolerate elevated nutrient concentrations (Chavez et al. 1991, Vaulot \& Partensky 1992). There are several possible interpretations of the inverse relationship. First, high nutrients in marginal seas are usually associated with coastal waters where other factors (including land 


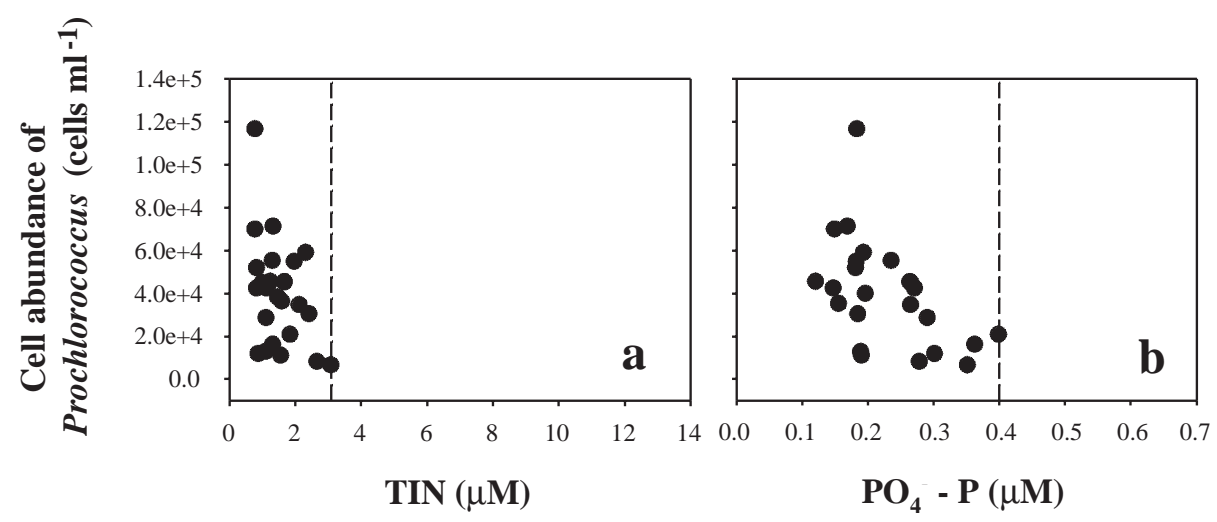

Fig. 6. Relationship between Prochlorococcus and (a) total inorganic nitrogen (TIN) and (b) $\mathrm{PO}_{4}$-P in the East China Sea, indicating the corresponding thresholds above which Prochlorococcus disappeared. (Only data from the surface mixed layer were included to avoid possible interference by high nutrient concentrations at the bottom of the euphotic zone.) $x$-axis scales up to nutrient levels recorded in the surface mixed layer

input materials) may also be important in regulating picoplankton dynamics. Secondly, high nutrient conditions favor those whose maximum growth rates are higher than Prochlorococcus, such as Synechococcus (Moore et al. 1995). Furthermore, recent work has revealed that only the low-light ecotype Prochlorococcus strain can take up nitrite and that none of the Prochlorococcus strains in culture can utilize nitrate due to lack of nitrate reductase genes (Moore et al. 2002). Thus, high nitrate concentration favors other picoplankters other than Prochlorococcus. Therefore, the observed inverse relationship between Prochlorococcus and macronutrients is due either to non-causal correlation or to Prochlorococcus being outcompeted where nutrients are replete but in an unavailable form to Prochlorococcus (López-Lozano et al. 2002, Moore et al. 2002); furthermore, the maximum growth rate of Prochlorococcus is lower than that of other species such as Synechococcus (Moore et al. 1995, CavenderBares et al. 2001).

Along trophic gradients from the estuary to the oceanic water, pico-eukaryotes showed a very similar pattern for the different transects. High abundance occurred immediately out of the river plume, where nutrients were still abundant but turbidity was fairly low (Stns 107, 406, 705 and 903) and another high abundance zone formed in the front areas of cold and warm water masses (Stns 113, 410, 713 and 909).

Synechococcus showed a general pattern similar to that of pico-eukaryotes, but its high abundance usually centered shallower in depth and closer to shore than did pico-eukaryotes. The distribution of Synechococcus can be understood in terms of nutrient availability and light availability. Generally, Synechococcus is positively correlated with nitrogen concentrations (Table 1), but in the Yangtze River estuary area, although nutrient level was very high, Synechococcus abundance could be very low due to low transparency, e.g. at Transects 1 and 4, Synechococcus abundance increased dramatically with increasing transparency and reached their peak values where transparence was about 5 to $8 \mathrm{~m}$ (Fig. 7). Synechococcus decreased with increasing transparency as nutrient availability became more limiting than light availability. This pattern is similar to that in previous studies of the Yangtze River estuary (Vaulot \& Ning 1988), although the observation scale is not the same.

Table 1. Correlation coefficients between picoplankton cell abundances and physical and chemical factors in the East China Sea in July 1998. (Data from all sampling depths are included for the statistics in this table; only coefficients of significance at the $\mathrm{p}<$ 0.01 level are shown; + and -: positive and reverse relationship respectively.) Syn: Synechococcus; Pro: Prochlorococcus; Euk: picoeukaryotes; Bact: heterotrophic bacteria; TIN: total inorganic nitrogen

\begin{tabular}{|c|c|c|c|c|c|c|c|c|c|}
\hline Picoplankton & Temp. $\left({ }^{\circ} \mathrm{C}\right)$ & Salinity (psu) & $\mathrm{PO}_{4}-\mathrm{P}$ & $\mathrm{SiO}_{4}-\mathrm{Si}$ & $\mathrm{NO}_{2}-\mathrm{N}$ & $\mathrm{NO}_{3}-\mathrm{N}$ & $\mathrm{NH}_{4}-\mathrm{N}$ & TIN & TIN:P \\
\hline Syn $(n=220)$ & + & -0.46 & - & +0.27 & + & +0.38 & + & +0.33 & +0.44 \\
\hline Pro $(n=161)$ & +0.39 & + & -0.44 & -0.48 & -0.30 & -0.42 & - & -0.35 & - \\
\hline Euk $(n=220)$ & + & - & - & + & + & + & + & + & + \\
\hline Bact $(\mathrm{n}=220)$ & _ & -0.44 & + & +0.54 & +0.42 & +0.50 & +0.45 & +0.64 & +0.56 \\
\hline
\end{tabular}




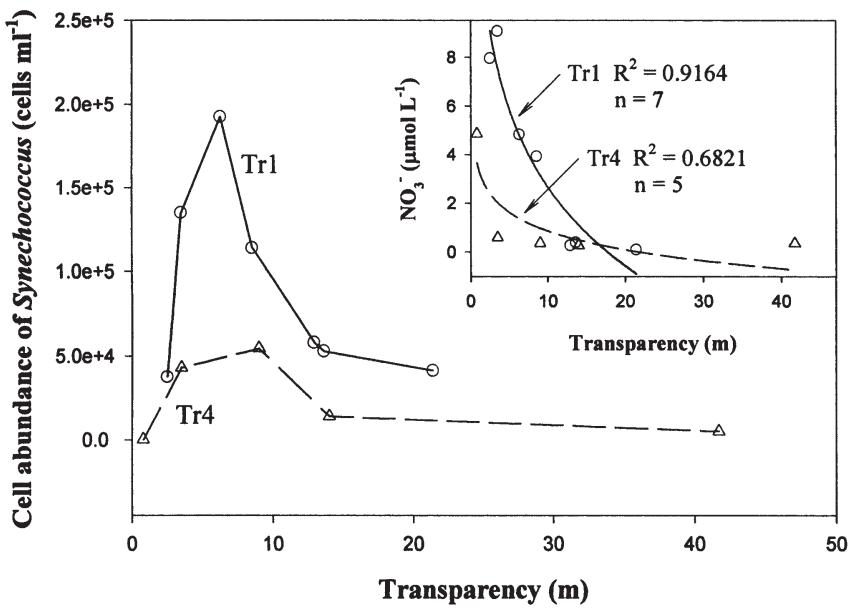

Fig. 7. Variation of cell abundance of Synechococcus with transparency. The upper-right inner chart indicates the inverse correlation between transparency and nutrient at Transects 1 and 4 (Tr1 and Tr4). Notice that the Synechococcus abundance peak values at Transect 1 were higher than those at Transect 4 , due to higher nutrient availability at Transect 1 than at Transect 4

Bacteria, presumably uninfluenced by light, were most abundant in the plume area where nutrients were replete and dissolved organic carbon resources were rich (Zhao 2000) although light availability was low.

The species composition of pico-eukaryotes may have changed over regions and water masses in the ECS, as we noticed subtle variations in the location of 'pico-eukaryote groups' in flow cytometry plots of samples from different areas. The high abundance zone at the subsurface of Stn 804 was probably formed by oceanic species rather than coastal species. Therefore, the geographic distribution pattern of pico-eukaryotes in the ECS should not be simply attributed to effects of physical-chemical factors.

Similarly the 2 high abundance zones of Synechococcus at Stns 709 and 713 were likely formed by oceanic populations different from the one centered near the coast. We were able to discriminate the 'high cellular phycourobilin to phycoerythrobilin (PUB:PEB) ratio population' in oceanic waters from the 'low PUB:PEB ratio population' (Wood et al. 1985, Olson et al. 1988, Campbell et al. 1998) in the coastal water for the winter cruise in the same area of the sea. Because cytographic overlaps between the 2 populations were severe for the summer samples, we treated the 2 as a single group for the present study to simplify the comparison between Synechococcus and others.
In contrast to Prochlorococcus, which was basically associated with oligotrophic conditions, Synechococcus, pico-eukaryotes and bacteria populations seem to be associated more with eutrophic conditions. By converting cell abundance to cell biomass using the factors widely applied-53 $\mathrm{fgC} \mathrm{cell}^{-1}$ for Prochlorococcus, $250 \mathrm{fg} \mathrm{C} \mathrm{cell}^{-1}$ for Synechococcus, $2100 \mathrm{fg} \mathrm{C} \mathrm{cell}^{-1}$ for picoeukaryotes and $20 \mathrm{fg} \mathrm{C} \mathrm{cell}^{-1}$ for heterotrophic bacteria (Morel et al. 1993, Campbell et al. 1994, Buck et al. 1996) - it can be seen that biomass of bacteria is positively correlated with the sum of that of Synechococcus and pico-eukaryotes in the study area out of the estuary (Fig. 8a), while it is negatively correlated with that of Prochlorococcus (Fig. 8b). Such an inverse relationship between Prochlorococcus and bacteria was also found in the Arabian Sea (Campbell et al. 1998). Since Prochlorococcus can flourish in stratified nutrient-deplete waters (Olson et al. 1990, Campbell \& Vaulot 1993, Lindell \& Post 1995), and bacteria is generally more abundant in the nutrient-rich coastal areas (Fuhrman 1999), the inverse relationship between the two seems to be another feature of the transitional zones between oligotrophic and eutrophic regimes.

\section{The role of water mass in determining the distribu- tion of Prochlorococcus in the marginal sea}

From Fig. 9, it can be seen that in the surface mixed layer, Prochlorococcus disappeared when temperature was below $26^{\circ} \mathrm{C}$ and salinity was less than 30 psu in the study period (Fig. 9a). While in the deep water below the mixed layer, the corresponding thresholds recorded were $16^{\circ} \mathrm{C}$ and 33.4 psu respectively (Fig. 9b). Obviously, temperature, the most crucial factor regulating Prochlorococcus's distribution on a basin scale, was not a reliable criterion for the situation in marginal seas. It was most likely that the combination

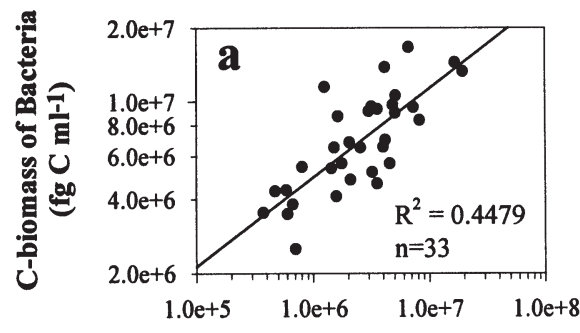

Total C-biomass of Synechococcus and pico-eukaryotes (fg $\mathrm{C} \mathrm{ml}^{-1}$ )

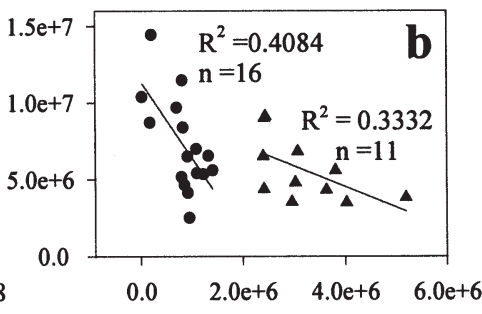

C-biomass of Prochlorococcus (fg $\mathrm{C} \mathrm{ml}^{-1}$ )
Fig. 8. Relationship between depth-weighted average carbon-biomass (fg C $\mathrm{ml}^{-1}$ ) of bacteria and (a) the sum of Synechococcus and pico-eukaryotes at the stations out of the estuarine area, and (b) Prochlorococcus ( $\mathbf{\Delta}$ : oceanic stations located in the main stream of Kuroshio Current and Taiwan Warm Current; -: shelf stations or stations across trophic gradients) 
of multivariables associated with water mass determined the distribution scope of Prochlorococcus in marginal seas.

The association of Prochlorococcus with particular water masses and currents is supported by the more shoreward distribution of Prochlorococcus along Transect 4, where the Taiwan Warm Current reached, than along Transect 1, where Prochlorococcus was present from Stn 113 eastward, much farther away from the estuary. This pattern was consistent with the distribution of water currents (Su 1989): the Taiwan Warm Current proceeded up to the Yangtze River estuary area but stopped by the Yellow Sea Cold Eddy in

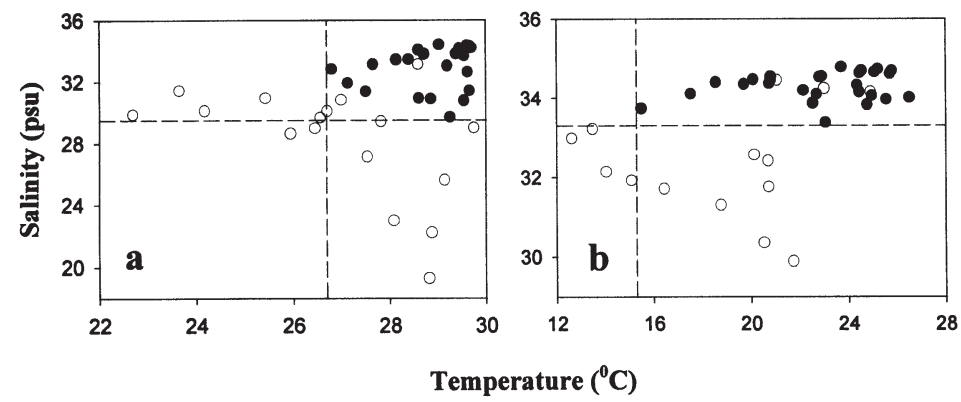

Fig. 9. Distribution of stations in a temperature-salinity plot, indicating corresponding thresholds below which Prochlorococcus disappeared. (a) Surface mixed layer; (b) deep layer below. •: stations where Prochlorococcus were present; o: stations where no Prochlorococcus were detected the summer time (Fig. 1). Meanwhile, the Yellow Sea Coastal Current from the north side proceeded southward along the 40 to $50 \mathrm{~m}$ isobath to $32^{\circ} \mathrm{N}$ (Transect 1 ) and, in conjunction with the 'cold eddy', formed the cold water system. In between the cold and warm water systems there was a boundary roughly paralleling the $50 \mathrm{~m}$ isobath near the river plume. Prochlorococcus suddenly disappeared at Stn 406 (cold water system), only about $60 \mathrm{~km}$ west of Stn 408 where the warm water current passes through and Prochlorococcus was very abundant. This is consistent with the situation of the Gulf Stream in the North Atlantic, where Prochlorococcus abruptly declined off the stream on both sides and dropped below the detection limit on the coastal water side (Cavender-Bares et al. 2001, Jiao unpubl. data).

The effects of water mass can also be seen from the relationship between abundances of Prochlorococcus and Synechococcus (Fig. 4). In the middle of the Kuroshio Current (typically Stns 206 and 804), Prochlorococcus were 2 orders of magnitude more abundant than Synechococcus. At the edge of the Kuroshio Current (typically Stns 418 and 714), or in the weaker branches of the warm current (e.g. Stn 409), abundance of Prochlorococcus was 1 order of magnitude greater than that of Synechococcus. In the front areas between the warm current branches and the shelf water masses (e.g. Stns 410, 115 and 907), abundances of the 2 genera were comparable. In the coastal waters (e.g. Stns 103, 106 and 404), Prochlorococcus were absent and Synechococcus were very abundant.

Given the environmental conditions in the ECS, the distribution of Prochlorococcus is most likely controlled fundamentally by oceanic currents and relevant water masses over a large spatial scale. Locally, temperature, nutrients and water column structures may also play additional roles. Unlike the situation in the oceans, the sudden change in cell abundance within a relatively short distance seems to be a typical feature of marginal seas.

\section{Characteristics of depth profile of Prochlorococcus in the marginal sea}

Partensky et al. (1999) summarized the worldwide data on Prochlorococcus and classified Prochlorococcus vertical distribution patterns into 3 types with respect to its depth profile shape and relative abundance to Synechococcus. In the present study, although there were no such typical patterns as in the oligotrophic tropical oceans, 2 types of Prochlorococcus depth profile can be roughly distinguished. One type allocated to the Kuroshio Current area was characterized by deep distribution of Prochlorococcus with abundance at least an order of magnitude higher than Synechococcus (typically Stns 206, 418 and 804, see Fig. 4). The other type was characterized by Prochlorococcus abundance peaking at the surface layer and dropping to an abundance comparable to that of Synechococcus above the nitracline (typically Stns 115, 410, 905 and 907). The latter type is similar to the description of Partensky et al. (1999) for the case of nearshore waters. There were also transitional types in the shelf waters. Unlike the situation of stratified oligotrophic waters, where Prochlorococcus maintain a maximum near the bottom of the euphotic zone (Olson et al. 1990, DuRand et al. 2001), the oceanic waters in the ECS were associated with the Kuroshio Current whose movements make the water column always mixed. Thus, there were no pronounced subsurface peaks in the depth profiles, although Prochlorococcus outnumbered Synechococcus by at least an order of magnitude, as is common in oceanic water (Campbell \& Vaulot 1993). This seems to be a specific biological feature of the marine current system in the marginal sea areas.

Acknowledgements. This study was supported by the NSFC Projects 40232021, 40176037, 2000078500 and 2001CB-409700. We thank the Chinese JGOFS Program and Prof. D. Hu for providing the physi-chemical data. We also thank the 2 anonymous reviewers for their valuable comments and suggestions. 


\section{LITERATURE CITED}

Binder BJ, Chisholm SW, Olson RJ, Frankel SL, Worden AZ (1996) Dynamics of picoplankton, ultraphytoplankton and bacteriaeria in the central equatorial Pacific. Deep-Sea Res 43:907-931

Buck KR, Chavez FP, Campbell L (1996) Basin-wide distributions of living carbon components and the inverted trophic pyramid of the central gyre of the north Atlantic Ocean, summer 1993. Aquat Microb Ecol 10:283-298

Bustillos-Guzman J, Claustre H, Marty JC (1995) Specific phytoplankton signatures and their relationship to hydrographic conditions in the coastal northwestern Mediterranean Sea. Mar Ecol Prog Ser 124:247-258

Campbell L, Vaulot D (1993) Photosynthetic picoplankton community structure in the subtropical North Pacific Ocean near Hawaii (station ALOHA). Deep-Sea Res 40: 2043-2060

Campbell L, Nolla HA, Vaulot D (1994) The importance of Prochlorococcus to community structure in the central North Pacific Ocean. Limnol Oceanogr 39:954-961

Campbell L, Landry MR, Constantinou J, Nolla HA, Brown SL, Liu H, Caron DA (1998) Response of microbial community structure to environmental forcing in the Arabian Sea. Deep-Sea Res 45:2301-2325

Cavender-Bares KK, Karl DM, Chishlom SW (2001) Nutrient gradients in the western North Atlantic Ocean: relationship to microbial community structure and comparison to patterns in the Pacific Ocean. Deep-Sea Res I 48(11): 2373-2395

Chavez FP, Buck K, Coale K, Martin JH, DiTullio GR, Welschmeyer NA (1991) Growth rates, grazing, sinking and iron limitation of equatorial Pacific phytoplankton. Limnol Oceanogr 36:1818-1833

Chisholm SW, Olson RJ, Zettler ER, Goerick R, Waterbury JB, Welschmeyer NA (1988) A novel free-living prochlorophyte abundant in the oceanic euphotic zone. Nature 334: 340-343

Chisholm SW, Frankel SF, Goericke R, Olson RJ, Palenik B, Waterbury JB, West-Johnsrud L, Zettler ER (1992) Prochlorococcus marinus nov. gen. nov. sp.: an oxyphototrophic marine prokaryote containing divinyl chlorophyll a and b. Arch Microbiol 157:297-300

DuRand MD, Olson RJ, Chisholm SW (2001) Phytoplankton population dynamics at the Bermuda Atlantic Time-series Station in the Sargasso Sea. Deep-Sea Res 48(8-9): 1983-2003

Fuhrman JA (1999) Marine virus and their biogeochemical and ecological effects. Nature 541-548

Furuya K, Kurita K, Odate T (1996) Distribution of phytoplankton in the East China Sea in the winter of 1993. J Oceanogr 52:323-333

Hama T, Shin KH, Handa N (1997) Spatial variability in the primary productivity in the East China Sea and its adjacent waters. J Oceanogr 53:41-51

Jiao N, Yang Y (1999) Distribution of Prochlorococcus, Synechococcus and pico-eukaryotes in the East China Sea. Bull Inst Oceanogr 19:435 442

Jiao N, Yang Y, Mann E, Chisholm SW, Chen N (1998) Winter presence of Prochlorococcus in the East China Sea. Chin Sci Bull 43:877-878

Li WKW (1995) Composition of ultraphytoplankton in the central North Atlantic. Mar Ecol Prog Ser 122:1-8

Lindell D, Post AF (1995) Ultraphytoplankton succession is triggered by deep winter mixing in the Gulf of Aqaba (Eilat), Red Sea. Limnol Oceanogr 40(6):1130-1141

López-Lozano A, Diez J, Alaoui SE, Moreno-Vivián C, García-Fernández JM (2002) Nitrate is reduced by heterotrophic bacteria but not transferred to Prochlorococcus in non-axenic cultures. FEMS Microbiol Ecol 24(2):151-160

Marie D, Partensky F, Jacquet S, Vaulot D (1997) Enumeration and cell cycle analysis of natural populations of marine picoplankton by flow cytometry using the nucleic acid stain SYBR Green I. Appl Environ Microbiol 63: 186-193

Moore LR, Georicke R, Chisholm SW (1995) Comparative physiology of Synechococcus and Prochlorococcus: influence of light and temperature on growth, pigments, fluorescence and absorptive properties. Mar Ecol Prog Ser 116:259-275

Moore LR, Post AF, Rocap G, Chisholm SW (2002) Utilization of different nitrogen sources by the marine cyanobacteria Prochlorococcus and Synechococcus. Limnol Oceanogr 47:989-996

Morel A, Ahn YH, Partensky F, Vaulot D, Claustre H (1993) Prochlorococcus and Synechococcus: a comparative study of their optical properties in relation to their size and pigmentation. J Mar Res 51:617-649

Olson RJ, Chisholm SW, Zettler ER, Armbrust EV (1988) Analysis of Synechococcus pigment types in the sea during single and dual beam flow cytometry. Deep-Sea Res 35:425-440

Olson RJ, Chisholm SW, Zettler ER, Altabet MA, Dusenberry JA (1990) Spatial and temporal distributions of prochlorophyte picoplankton in the North Atlantic Ocean. DeepSea Res 37:1033-1051

Partensky F, Hess WR, Vaulot D (1999) Prochlorococcus, a marine photosynthetic prokaryote of global significance. Microbiol Mol Biol Rev 63(1):106-127

Sawarh T (1974) On the sea surface temperature in the East China Sea for the years 1953-1972. Oceanogr Mag 26: $17-26$

Su Y (1989) A survey of geographical environment circulation system in the Huanghai Sea and East China Sea. J Ocean Univ Qingdao 19:145-158

Vaulot D, Ning X (1988) Abundance and cellular characteristics of marine Synechococcus spp in the dilution zone of the Changjiang (Yangtze ) River China. Cont Shelf Res 8: 1171-1186

Vaulot D, Partensky F (1992) Cell cycle distribution of prochlorophytes in the north western Mediterranean Sea. Deep-Sea Res 39:727-742

Vaulot D, Couties C, Partensky F (1989) A simple method to preserve oceanic phytoplankton for flow cytometric analysis. Cytometry 10:629-635

Vaulot D, Partensky F, Neveux J, Mantoura RFC, Llewellyn CA (1990) Winter presence of prochlorophytes in surface waters of the northwestern Mediterranean Sea. Limnol Oceanogr 35:1156-1164

Wood AM, Horan PK, Muirhead K, Phinney DA, Yentsch CM, Waterbury JB (1985) Discrimination between types of pigments in marine Synechococcus spp. by scanning spectroscopy, epifluorescence microscopy, and flow cytometry. Limnol Oceanogr 30:1303-1315

Zhao WH (2000) A biogeochemical study of nutrients and organic carbon in the typical coastal areas of China. Postdoctoral Report, Institute of Oceanology, Chinese Academy of Sciences, Qingdao, p 1-210

Submitted: Novemver 28, 2001; Accepted: August 19, 2002

Proofs received from author(s): November 5, 2002 